\title{
Racial Health Disparity and COVID-19
}

\author{
Santosh Kumar ${ }^{1}$ - Prashant Kumar ${ }^{2} \cdot$ Sunitha Kodidela ${ }^{1} \cdot$ Benjamin Duhart $^{3} \cdot$ Alina Cernasev $^{4} \cdot$ Anantha Nookala $^{5}$. \\ Asit Kumar ${ }^{1}$. Udai P. Singh ${ }^{1} \cdot$ John Bissler ${ }^{2}$
}

Received: 7 May 2021 / Accepted: 19 August 2021/Published online: 9 September 2021

(C) The Author(s), under exclusive licence to Springer Science+Business Media, LLC, part of Springer Nature 2021

\begin{abstract}
The infection by severe acute respiratory syndrome coronavirus-2 (SARS-CoV-2) and resultant coronavirus diseases-19 (COVID-19) disproportionally affects minorities, especially African Americans (AA) compared to the Caucasian population. The AA population is disproportionally affected by COVID-19, in part, because they have high prevalence of underlying conditions such as obesity, diabetes, and hypertension, which are known to exacerbate not only kidney diseases, but also COVID-19. Further, a decreased adherence to COVID-19 guidelines among tobacco smokers could result in increased infection, inflammation, reduced immune response, and lungs damage, leading to more severe form of COVID-19. As a result of high prevalence of underlying conditions that cause kidney diseases in the AA population coupled with tobacco smoking make the AA population vulnerable to severe form of both COVID-19 and kidney diseases. In this review, we describe how tobacco smoking interact with SARS-CoV-2 and exacerbates SARS-CoV-2-induced kidney diseases including renal failure, especially in the AA population. We also explore the role of extracellular vesicles (EVs) in COVID-19 patients who smoke tobacco. EVs, which play important role in tobacco-mediated pathogenesis in infectious diseases, have also shown to be important in COVID-19 pathogenesis and organ injuries including kidney. Further, we explore the potential role of EVs in biomarker discovery and therapeutics, which may help to develop early diagnosis and treatment of tobacco-induced renal injury in COVID-19 patients, respectively.
\end{abstract}

Keywords SARS-CoV-2 $\cdot$ COVID-19 $\cdot$ Kidney disease $\cdot$ Renal injury $\cdot$ Tobacco smoking $\cdot$ Health disparity $\cdot$ Extracellular vesicles

Santosh Kumar and Prashant Kumar equally contributed to this work.

Santosh Kumar

ksantosh@uthsc.edu

$\square$ John Bissler

jbissler@uthsc.edu

1 Department of Pharmaceutical Sciences, College of Pharmacy, University of Tennessee Health Science Center, Memphis, TN, USA

2 Department of Pediatrics, University of Tennessee Health Science Center and Le Bonheur Children's Hospital, Memphis, TN, USA

3 Department of Clinical Pharmacy and Translational Science, University of Tennessee Health Sciences Center, Memphis, TN, USA

4 Department of Clinical Pharmacy and Translational Science, University of Tennessee Health Sciences Center, Nashville, TN, USA

5 Covance Inc., Kinsman Blvd, Madison, WI, USA

\section{Introduction}

Severe acute respiratory syndrome coronavirus-2 (SARSCoV-2) infection, which causes coronavirus diseases-19 (COVID-19), not only infects the lungs, but also other organs such as the heart, kidney, intestine, liver, and brain (Lopes-Pacheco et al. 2021). The disease severity and mortality are extremely high amongst elderly individuals and populations with co-morbid conditions, especially obesity, hypertension, and diabetes mellitus (Flook et al. 2021). These conditions are also known to cause kidney diseases or renal failure, which is further exacerbated by SARS-CoV-2 infection (Kooman and van der Sande 2020; Lim et al. 2020; Mousavi Movahed et al. 2021). Unfortunately, these conditions are relatively more common among African American (AA) than Caucasian American (CA) populations (Pi-Sunyer 1990; CDC 2017). Thus, the high degree of kidney diseases among the AA population is further exacerbated by relatively high prevalence of COVID-19 in the AA population. 
During the pandemic, the "Work-from-Home" or "Safeat-Home" order that led to social isolation and loss of jobs and incomes unfortunately also affected the AA population disproportionately (Bland et al. 2021; Obinna 2021). In addition, their role as emergency workers in many industries made the AA population more vulnerable to SARS-CoV-2 infection. These factors caused severe stress and anxiety, particularly among the AA populations, and also increased the use of legal and illicit substances (Gur et al. 2020; Miller 2021; Snowden and Snowden 2021; Wang et al. 2021). Further, individuals with tobacco smoking disorder in the AA population have increased the risk for COVID-19 and its adverse outcomes (Wang et al. 2021).

SARS-CoV-2 infects many different cell types by attaching angiotensin-converting enzyme 2 (ACE2) receptor, which in addition to lungs, is also expressed in other organs including the kidney (Albini et al. 2020). Thus, SARSCoV-2 infection to the kidney triggers massive cytokine responses, immune compromise, and kidney or renal injury (Stasi et al. 2020). Recent findings also suggest that nicotine via alpha7-nicotinic receptor induces ACE2 expression, which may exacerbate tobacco-mediated COVID-19 pathogenesis (Leung et al. 2020; Russo et al. 2020). Thus, it is important to understand the relationships between tobacco use, COVID-19 severity, and renal injury or failure, which disproportionately affect the AA population.

In this review, we describe how tobacco smoking interacts with SARS-CoV-2 and exacerbates SARS-CoV-2induced renal failure, especially in the AA population. We also explore the role of extracellular vesicles (EVs), which are known to carry biological molecules and trigger intercellular communication within different cells in tobacco smokers and COVID-19 patients. EVs have been shown to play important role in COVID-19 pathogenesis and various organ injury including kidneys (Pocsfalvi et al. 2020; Zadjali et al. 2020). EVs are also known to play a role in tobaccomediated pathogenesis in infectious diseases (Kodidela et al. 2018; Haque et al. 2020a, b). Finally, we will discuss the potential role of EVs in biomarker discovery and therapeutic interventions with regards to smoking-induced COVID-19 pathogenesis and kidney injury.

\section{Tobacco Smoking and COVID-19 Pathogenesis}

Although the number of secondhand smoke exposure among American nonsmokers has decreased in the last three decades, approximately 40 million American adults continue smoking cigarettes. Furthermore, the CDC's findings indicate that approximately 4.7 million middle and high school students use at least one tobacco product, including e-cigarettes (Tsai et al. 2018). Smoking remains a major cause and contributor to mortality and morbidity in the U.S., with a majority of the burden being on people of color. A recent CDC report showed 480,000 deaths per year due to smoking and its related diseases in the U.S. Smoking enhances mortality from cardiovascular and metabolic diseases (95,600 deaths), as well as from respiratory diseases (58,200 deaths) (CDC 2020). Subsequently, smoking remains a prime contributor to the three major causes of death, heart disease, stroke, and cancer, in the AA population (CDC 2021a). Cigarette smoking is the leading cause of the cardiovascular disease (CVD) including atherosclerotic vascular disease, myocardial infarction, and unstable angina (Winniford 1990). The main pathway for CVD is via activation of inflammatory cytokines and chemokines, lipid oxidation, hypercoagulability, and vascular dysfunction (Winniford 1990). At the metabolic level, the response to smoking consists of an increased level of inflammatory markers, white blood cell (WBC) count, and urinary F2 isoprostanes, a lipid peroxidation product (King et al. 2017). CVD manifests as a rise in heart rate, blood pressure, and cardiac output (Winniford 1990).

At the respiratory level, the damaging effects of smoking are well documented. Smoking is a significant cause of the chronic obstructive pulmonary disease (COPD) and represents approximately $85 \%$ of COPD cases (Brashier and Kodgule 2012). It has been shown that AA and women with COPD are more susceptible to the deleterious effects of cigarette smoking when compared to Caucasians (Chatila et al. 2004). A study conducted in Cleveland with 15,586 participants tested for COVID-19 and found that $12 \%$ of COPD participants were positive for COVID-19 (Attaway et al. 2020). Furthermore, $48 \%$ of COVID-19 positive COPD participants required hospitalization, with $45 \%$ being admitted to the ICU (Attaway et al. 2020). Thus, Attaway et al. concluded that participants with underlying conditions such as COPD had a higher risk for hospitalization, ICU admission, and the usage of mechanical ventilation (Attaway et al. 2020). The impact of COVID-19 severity and death caused by the disease is mounting on the people of color, especially AA. (Andrasfay and Goldman 2021; Gold et al. 2020). Nationwide studies investigating teenagers and young adults found that smoking and e-cigarettes represent an underlying risk factor for COVID-19 (Gaiha et al. 2020a, b). Further, a study also showed that AA who are tobacco smokers are more likely to experience COVID related symptoms (Gaiha et al. 2020a). Thus, smoking puts people of color at a higher risk for contracting COVID-19 as well as a poorer prognosis.

A recent CDC report shows that $33 \%$ of those hospitalized patients were black whereas AA constitute about $13 \%$ of the US population (Garg et al. 2020). Further, the CDC report shows that although the infection rate is similar, the AA population with a confirmed COVID-19 diagnosis has 
2.9-times more hospitalization and 2-times more death when compared with the CA population (CDC 2021b).

One plausible reason for these disparities in the AA, along with higher mortality in this population, is attributed to the socioeconomic disadvantages that have been augmented during the current pandemic (Kodidela et al. 2020a). The mechanisms for the disproportionate effects on people of color are not well understood; thus, a team of researchers in the UK investigated the potential connection between Vitamin D deficiency and risk factors for contracting the infection in the black population (Hastie et al. 2020). Specifically, the research team examined if COVID-19 risk was linked to blood 25-hydroxyvitamin D (25(OH)D) (Hastie et al. 2020). However, the study found no evidence for a possible connection between COVID-19 risk and low blood 25-hydroxyvitamin D (Hastie et al. 2020).

Individuals who contract with SARS-CoV-2 present various symptoms. While some persons may present with mild flu-like symptoms, others displayed multi-organ failure, kidney being of the main organs affected in severe illness and required renal replacement therapy (RRT). Previous studies reported that individuals diagnosed with chronic kidney disease (CKD) presented with high levels of ACE2, enabling the entry of the COVID-19 virus into human cells (Anguiano et al. 2017; Hirsch et al. 2020). Pranata et al. conducted systematic literature on the correlation between CKD and new-onset RRT, concluding that CKD and new-onset RRT were linked and presented with poor outcomes in COVID19 positive participants (Pranata et al. 2020). Furthermore, researchers at Mount Sinai Health System in New York investigated participants with CKD and COVID-19 positive diagnoses (Yamada et al. 2020). They concluded that CKD patients presented with poorer outcomes, including a higher risk of intubation and death.

\section{Smoking and COVID-19 in Kidney Diseases, Especially with Regards to the AA Population}

\section{Smoking and Renal Failure}

According to the USRDS 2020 Annual Report, AA patients have an adjusted prevalence of End Stage Renal Disease (ESRD) that is 3.4-fold higher than White patients (United States Renal Data System 2020). Potential factors for this disparity identified both hypertension and lower socioeconomic status as significant factors for the increased prevalence of ESRD in AA patients (Klag et al. 1997). Due to stimulation of the sympathetic nervous system through the production of catecholamines by nicotine as well as endothelial cell dysfunction, which may cause arterial stiffness, smoking has been associated with the development of hypertension (Klag et al. 1997; Virdis et al. 2010). Previous studies have shown that hypertension is also associated with the progression of kidney disease. Consequently, smoking may also contribute to the disparities noted in ESRD for the AA population, as has also been reported recently in the Korean population (Choi et al. 2019). Recently, Li et. al has reported that heavy smokers ( $\geq 1$ pack per day) with ESRD requiring hemodialysis have an estimated $41 \%$ increased risk of mortality, which was higher than coronary artery disease, congested heart failure, and diabetes alone. In addition, an increased risk of hospitalization was also identified for the same group of patients. In this study, the population of AA patients enrolled was $31 \%$ ( $\mathrm{Li}$ et al. 2018). Further, a study in an AA cohort demonstrated the independent association between cigarette smoking and rapid renal function decline (Hall et al. 2016).

\section{COVID-19 and Renal Failure}

Due to the increase in substance use during the COVID-19 pandemic, smoking is of grave concern, because smoking is associated with an increased incidence and progression of CKD. Previous studies noted smoking as a risk factor for the development of CKD (Halimi et al. 2000; Halimi and Mimran, 2000). For example, effects of current smoking and smoking discontinuation on renal function and proteinuria in the general population have been reported (Haroun et al. 2003). However, the results of the retrospective analysis of patients enrolled in the Study of Heart and Renal Protection (SHARP) provided contrasting views on the relevance of smoking as a risk factor for kidney disease progression. Authors reported that smoking adversely affected vascular and nonvascular morbidity and mortality, but not kidney disease progression. Of note, the demographics of AA patients enrolled was $\leq 5 \%$ of the population; thus, it's difficult to extrapolate to the AA community. Conversely, Xia et. al performed a meta-analysis of prospective cohort studies and confirmed that smoking was an independent risk factor for CKD/ESRD (Xia et al. 2017).

AA ethnicity has been linked to an increased incidence of CKD in the United States (CDC 2021b). In addition, analysis of Open Safely, a secure health analytics platform, has shown that kidney disease is a risk factor for severe COVID19-related death (Williamson et al. 2020). Herein, we will discuss the renal disease in association with COVID-19 infection. The kidney is susceptible to SARS-CoV-2 due to the expression of ACE2 receptors on the brush border of the proximal tubules as well as in podocytes (MartinezRojas et al. 2020). The virus is capable of causing injury to the tubules as well as podocytes. The development of collapsing glomerulopathy, fibrin thrombi, and proximal tubule injury have been shown within the specimen from the kidney biopsy of COVID-19-infected patients (Gaillard 
et al. 2020; Kissling et al. 2020; Larsen et al. 2020; Su et al. 2020). As a result of the tubular damage, acute kidney injury (AKI) evolves along with symptoms of proteinuria, hematuria, and increased serum creatinine. Patients with COVID19 that develop AKI have an increased risk of mortality and the risk increases further if renal replacement therapy is necessary (Fisher et al. 2020; Hirsch et al. 2020; Yang et al. 2020). Furthermore, studies have shown that AA patients diagnosed with COVID-19 have an increased risk of developing AKI (Hirsch et al. 2020;). Since patients that suffer from COVID19-associated AKI experience an increased risk of mortality, AA patients may also experience an increased risk of death from COVID-19 due to the development of renal failure.

\section{Smoking-exacerbated Renal Failure in COVID-19 Patients}

As discussed in the previous section, smoking is a risk factor for various diseases including renal. In this section, we present how smoking could affect the renal function and will link this phenomenon in COVID-19 patients (Fig. 1). Various studies have shown the pathological effect of cigarette smoking in the development of CKD (Yacoub et al. 2010; Xia et al. 2017). As discussed before, COVID-19 infection is generally more severe in those people who have an underlying medical condition, such as obesity, diabetes, cardiovascular, and renal (Sanyaolu et al. 2020). It is well established that cigarette smoking affects the renal function and leads to renal failure (Xia et al. 2017). A Study has shown that smoking more than 30 packs of cigarettes in a year can severely damage kidney function and leads to the development of CKD (Yacoub

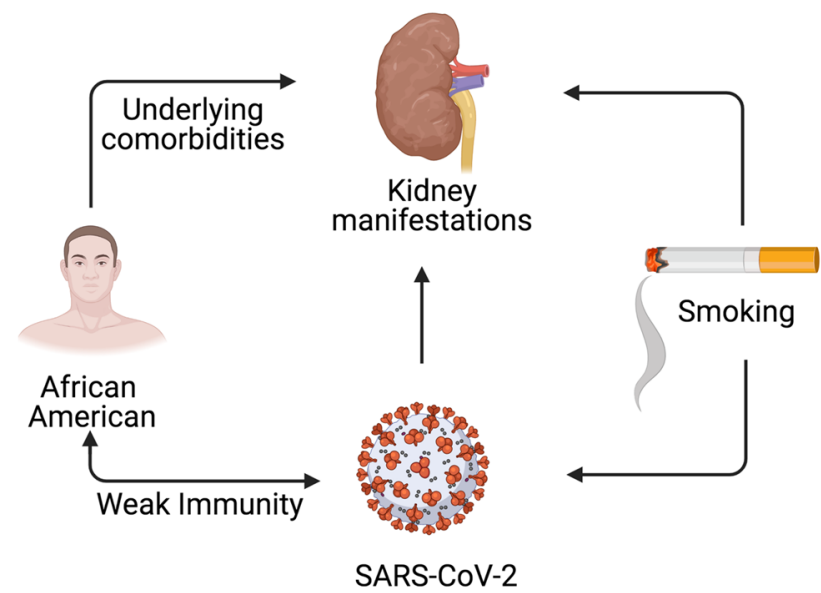

Fig. 1 Smoking and racial factors on SARS-CoV-2 and Kidney pathogenesis. Smoking weakens individuals' immunity and make them more susceptible to SARS-CoV-2 infection. Smoking also affect the kidney functions. There is a prevalence of both SARS-CoV-2 infection and kidney diseases among African American populations due to the presence of underlying comorbidities, which is further exacerbated by smoking et al. 2010). ACE2 is one of the crucial receptors which help the SARS-CoV-2 virus to infect the cell (Zamorano Cuervo and Grandvaux 2020). This receptor is naturally present in the cell membrane of the cell lining of various organs such as kidneys, lungs, and heart (Wysocki et al. 2020), which help the SARS-CoV-2 to infect kidney cells. Approximately, 25\% of the COVID-19 patient have been reported with AKI (Gabarre et al. 2020) and smoking, has been found to exacerbate the rate of renal failure to end-stage renal pathogenesis (Orth 2000).

Although, there are not many studies are available to show the effect of smoking on nephrolithiasis, one study with a small-scale patient group shows the relationship between cigarette smoking and the formation of kidney stones (Jones et al. 2021). Even though the formation of kidney stone is a multifactorial process, tobacco smoke, which contains a variety of heavy metals such as chromium, cadmium, lead, and nickel, could help formation of kidney stones (Stojanovic et al. 2004; Richter et al. 2009). Generally, exposure to cadmium may lead to the formation of kidney stones (Ferraro et al. 2011), which may lead to the development of CKD as a long-term consequence. This kind of underlying medical condition could help in acquiring a new SARS-CoV-2 infection. It is a well-known fact that smoking weakens the immune system of the body (CDC 2021c), which could serve as an invitation for any kind of new infection including SARS-CoV-2 infection. However, there is no direct clear data available to show that smoking can accelerate renal impairment in COVID-19 patients.

A recent metanalysis by Hansrivijit et al. considering the data from 26 studies $(n=5497)$ reported that the presence of AKI increases the risk of mortality by 13 -fold in patients with COVID19 (Hansrivijit et al. 2020). Various studies have also reported that CKD was the most prevalent risk factor for severe COVID-19 worldwide (Clark et al. 2020; Nadim et al. 2020; Council and Group 2021). Since smoking is an independent risk factor for severe COVID-19 (Xiang et al. 2021), it can exacerbate renal failure (Song et al. 2021) in COVID-19 patients. However, further research is needed to understand how smoking affects the renal function in people infected with SARS-CoV-2.

\section{Extracellular Vesicles in Cell-cell Communications in Smoking- and COVID-19-induced Renal Failure}

\section{Extracellular Vesicles in Cell-cell Communications}

Since their discovery in the late 1960s, extracellular vesicles (EVs) have been shown to play important roles in cell-to-cell communications with the neighboring and distant cells and regulate their biological processes (Colombo et al. 2014). 
EVs are phospholipid bilayer membrane structures of different sizes (30-1000 nm) released from various cell types (van Niel et al. 2018). They are broadly categorized into exosomes (30-200 nm) and microvesicles (200-1000 nm) based on their secretory pathways from the cell. The secretion of EVs from the cells is evolutionarily conserved from bacteria to humans (Deatherage and Cookson 2012). They serve as mediators of intercellular communication in normal physiological and pathological states by transferring the nucleic acids, proteins, and lipid cargoes to other cells (Paolicelli et al. 2019). Depending upon the cells from which EVs are produced, they may carry various cell surface receptors which help them to interact with a specific ligand expressed on the surface of the recipient cell. For instance, EVs released from mature dendritic cells contain intercellular adhesion molecule 1 on their surface which interacts with lymphocyte function-associated antigen on T-cell to induce T-cell activation (Segura et al. 2005). The EVs that do not carry cell surface receptors mediate intercellular communications by directly binding to the plasma membrane and transferring the cargoes to the recipient cells by phagocytosis and endocytosis (Mulcahy et al. 2014).

\section{Extracellular Vesicles in Smoking Mediated Pathogenesis}

EVs released under physiological conditions play important roles in maintaining homeostasis. Smoking affects the EV composition and contributes to the development of various smoking-induced pathological diseases such as COPD, cardiovascular diseases, asthma, non-small cell lung cancer, etc. (Benedikter et al. 2019). Active exposure to even one cigarette in healthy volunteers increases the number of circulating EVs containing nuclear molecules from platelets, endothelial cells, and leukocytes (Mobarrez et al. 2014; Kerr et al. 2019). A recent study, Feng et al. showed that the EVs isolated from bronchoalveolar lavage of smokers and nonsmall cell lung cancer patients were higher in concentration compared to that of non-smoker controls (Wu et al. 2019). Expression of several mRNA transcripts and long coding RNAs are dysregulated in the EVs of smokers compared to non-smokers. Also, the dysregulation profile of EVs in smokers closely resembles to stage IV non-small cell lung cancer patients indicating that smoking-induced EVs carry the tumor-associated genes (Wu et al. 2019). Exposure to cigarette smoke also increases the number of endothelial EVs with increased spermine content, which interacts with calcium-sensing receptors to induce pulmonary hypertension (Zhu et al. 2019a).

The EVs isolated from the serum of COPD patients show elevated levels of pro-inflammatory ligand-wnt5a, accompanied by an increase in the levels of various pro-inflammatory cytokines such as IL-6, TNF, IL-1 $\beta$, and IL-8 (Feller et al.
2018). This study underscores the role of EVs in transporting the pro-inflammatory components resulting in systemic inflammation in COPD (Feller et al. 2018). Endothelial cell damage is prominent in COPD and is characterized by an increase in the number of $\mathrm{CD} 31^{+}$circulatory endothelial microparticles, a marker of endothelial cell apoptosis (Thomashow et al. 2013). Cigarette smoke alone induces the release of $\mathrm{CD} 31^{+}$endothelial microparticles enriched with various miRNAs such as let-7d, $-126,-125-5 \mathrm{p},-22$, and -191 , which can interact with the healthy cells and modulate their functions (Serban et al. 2016). The EVs derived from lung epithelial cells have also been shown to affect the progression of COPD. Human bronchial epithelial cells treated with cigarette smoking induce the release of EVs containing full-length CCN1 (flCCN1), which increase the expression of IL-8 and VEGF, promoting inflammation and angiogenesis in the lung tissue, respectively. Further, cigarette smoke also promotes plasmin-mediated cleavage of flCCN1 to truncated CCN1(cCCN1), which induces the expression of matrix metalloproteinase- 1 and cause changes in lung emphysematous (Moon et al. 2014). In addition, cigarette smoke-induced EVs contribute to the development of COPD by disrupting the homeostasis between bronchial fibroblasts and epithelial cells and promote airway remodeling (Xu et al. 2018). EVs carrying miR-21 induce bronchial fibroblast differentiation by increasing the transcriptional activity of hypoxia-inducible factor- $1 \alpha$, which in turn, regulate the expression of alpha-smooth muscle actin, a marker of decreased lung function (Xu et al. 2018). Cigarette smoke also induces the secretion of EVs containing miR-210 from bronchial epithelial cells, which decrease autophagy by targeting ATG7, resulting in the differentiation of lung fibroblast to myofibroblast (Fujita et al. 2015). These results suggest that gene expression profile of small RNAs such as microRNA are altered in the plasma EVs of smokers with COPD compared to non-smokers, and these microRNAs can be utilized as biomarkers for understanding the disease progression (Sundar et al. 2019). Recently, Donate PB et al. have shown that cigarette smoke induces the expression of transcriptionally active miR-132-containing EVs, which contribute to the development of arthritis by inducing osteoclastogenesis (Donate et al. 2021).

Cigarette smoke also affects the immune system to facilitate smoking-mediated pathogenesis. In in vitro models, exposing the macrophages to tobacco smoke extract increase the secretion of EVs containing proteolytic matrix metalloproteinase-14, which subsequently damages the extracellular matrix leading to the development of various smoking-mediated pathologies (Li et al. 2013). In addition, macrophages treated with cigarette smoke condensate induce the release of EVs packed with pro-inflammatory chemokine RANTES and decreased antioxidant enzyme, superoxide dismutase1, ultimately changing the overall status of 
the EVs to pro-inflammatory (Haque et al. 2020b). Given the important role of EVs in the development of various smoking-mediated diseases, identifying the mechanisms of EV release might present a potential therapeutic option. Previously, Benedikter B. J et al. have shown that the release of EVs from the bronchial epithelial cells is mediated through the interaction of cigarette smoke components with the free thiol groups on the cell surface. Treatment with $\mathrm{N}$-acetyl cysteine significantly decreases the EV release, offering a potential treatment in COPD by decreasing the EV-mediated effects (Benedikter et al. 2017).

\section{Extracellular Vesicles in Renal Failure}

EVs are the undeserved and silent players in cellular communication in kidney. EVs can be found in various bodily fluids such as urine, blood, breast milk, amniotic fluid, saliva etc. (Doyle and Wang 2019). In this section, we will summarize the important findings, which corelates the EV and renal disorder (Table 1). In the case of renal system, urinary EVs are derived from kidney cells or the urinary tract (Kwon 2019). A recent in vitro and in vivo report also suggested the involvement of EV in renal manifestations (Kumar et al. 2021a, b). In addition to the diagnostic characteristics of EVs, they can also be considered as a biomarker for kidney impairment and damage. To understand the role of EVs on total kidney function, we first need to understand their role in the nephron. Nephron cells constitutively release EVs in healthy condition. In case of environmental stress, EV production can be increased (O'Neill et al. 2019) as well as the resultant EVs' characteristics also changes. Stress can also lead to change in the proteomics and genomics profile of EVs, which could serve as a biomarker in disease states (Zadjali et al. 2020). These EVs contain a variety of cargo molecules such as nucleic acids, proteins, lipids, and cell metabolites (He et al. 2018). These EV cargos mirror the parent cell and can be considered as the signature of their cell of origin. The Presence of renal primary cilia on the apical surface of nephron and collecting duct are the important characteristics of the nephron (Deane et al. 2013). Studies

Table 1 Summarizes the most recent study involving EVs in various renal diseases

\begin{tabular}{|c|c|c|c|}
\hline Renal disorder & Source of EV & Role of EV & Reference \\
\hline Diabetic kidney disease & $\begin{array}{l}\text { Human urine } \\
\text { and Mouse } \\
\text { Urine }\end{array}$ & $\begin{array}{l}\text { Lower expression of miR-26a can lead to the } \\
\text { progression of Podocyte Injury in Autoim- } \\
\text { mune Glomerulonephritis }\end{array}$ & (Ichii et al. 2014) \\
\hline $\begin{array}{l}\text { IgA nephropathy and thin basement } \\
\text { membrane nephropathy }\end{array}$ & Human Urine & $\begin{array}{l}\text { Change in proteomics; proteins (aminopepti- } \\
\text { dase } \mathrm{N} \text {, vasorin precursor, } \alpha \text {-1-antitrypsin, } \\
\text { and ceruloplasmin) } \\
\text { are differentially expressed }\end{array}$ & (Moon et al. 2011) \\
\hline $\begin{array}{l}\text { Tuberous sclerosis complex } \\
\text { (TSC) Complex }\end{array}$ & Cell culture EV & $\begin{array}{l}\text { Gene mutations changes the proteomics in } \\
\text { mutant cell and EV production }\end{array}$ & (Zadjali et al. 2020) \\
\hline $\begin{array}{l}\text { Autosomal dominant polycystic kidney } \\
\text { disease (ADPKD) }\end{array}$ & Human Urine & $\begin{array}{l}\text { Change in proteomics. Ratio of PC1/TMEM2 } \\
\text { [PC1 - polycystin1, TMEM2- } \\
\text { transmembrane protein 2] }\end{array}$ & (Hogan et al. 2015) \\
\hline Acute kidney injury & Human Urine & $\begin{array}{l}\text { Presence of activating transcription factor } 3 \\
\text { (ATF3) in the AKI patients }\end{array}$ & (Zhou et al. 2008) \\
\hline Renal cell carcinoma (RCC) & Human Urine & $\begin{array}{l}\text { Decreased expression of exosomal shuttle } \\
\text { RNAs (GSTA1, CEBPA and PCBD1) in the } \\
\text { RCC patients }\end{array}$ & (De Palma et al. 2016) \\
\hline $\begin{array}{l}\text { Autosomal dominant polycystic kidney } \\
\text { disease (ADPKD) }\end{array}$ & Human Urine & $\begin{array}{l}\text { Decreased level of AQP- } 2 \text { and Increase level } \\
\text { of APO-A1 in ADPKD patients }\end{array}$ & (Pocsfalvi et al. 2015) \\
\hline Renal carcinoma & Human Urine & $\begin{array}{l}\text { Differential protein profiling in EV produced } \\
\text { in RCC }\end{array}$ & (Raimondo et al. 2013) \\
\hline Medullary sponge kidney & Human Urine & $\begin{array}{l}\text { Changes in proteomics in medullary sponge } \\
\text { kidney patients }\end{array}$ & (Bruschi et al. 2019)31,018,934 \\
\hline Kidney transplantation & Human Urine & $\begin{array}{l}\text { Decreased expression of CD133 in kidney } \\
\text { transplanted patients }\end{array}$ & (Dimuccio et al. 2014) \\
\hline $\begin{array}{l}\text { Autosomal dominant polycystic kidney } \\
\text { disease (ADPKD) }\end{array}$ & Human Urine & $\begin{array}{l}\text { Decreased expression of miR-192-5p, miR- } \\
\text { 194-5p, miR-30a-5p, miR-30d-5p and miR- } \\
\text { 30e-5p in patients }\end{array}$ & (Magayr et al. 2020) \\
\hline Kidney transplantation & Human Urine & $\begin{array}{l}\text { Cyclosporine treated patient induces an } \\
\text { increase in NKCC } 2(\mathrm{Na}-\mathrm{K}-2 \mathrm{Cl} \text { cotrans- } \\
\text { porter in the loop of Henle) and NCC (Na- } \\
\mathrm{Cl} \text { cotransporter) }\end{array}$ & (Esteva-Font et al. 2014) \\
\hline
\end{tabular}


have shown the involvement of cilia in EV production and reception (Hogan et al. 2009). EVs associated with cilia have been involved in the pathogenies of polycystic kidney diseases (PKD) as shown by transmission electron microscopy in vivo (Hogan et al. 2009).

\section{Extracellular Vesicles in COVID-19 Pathogenesis}

The EVs and retroviruses such as SARS-CoV-2 share some of the important physical and biochemical characteristics. However, like viruses EV cannot multiply in a living cell. In this section, we will focus on the resemblance between $\mathrm{EV}$ and viruses and the role of EV in COVID-19 progression and the possible role of EV as therapeutic strategies. The resemblances between EVs and viruses are: 1) As some of the enveloped viruses, EVs also contain the phospholipid layer embedded with proteins like various other viruses; 2) EVs and viruses both have a size range in nanometer (100-300 nm); 3) Like most of the viruses, EVs also contain nucleic acid in its core; 4) Like viruses, EVs are also generated by the invagination of plasma membrane via endosomal sorting complexes required for transport (ESCRT) system (Colombo et al. 2014); 5) Like viruses, EVs can enter inside the cell via fusing to the plasma membrane. Further, EVs are known to facilitate viral infection. EVs are known to generate an immune response and trigger the production of inflammatory cytokines. SARS-CoV-2 is an RNA virus and belongs to a family of Coronaviridae. Coronaviruses are usually not lethal and generally cause mild to moderate respiratory tract infection like common flu. Coronaviruses mostly circulate between animals such as bats, cats, pigs, and camel. But sometime these viruses can jump from animal to human. Current type of coronavirus i.e., SARS-CoV-2 has a death rate of $>1 \%$ among infected patients, which increases with the age (Mahase 2020). SARS-CoV-2 encodes mainly four types of protein such as envelope protein (E), nucleocapsid protein $(\mathrm{N})$, Membrane protein $(\mathrm{M})$, and the spike protein (s). When a virus infected cell produces EVs, those EVs may not be as infectious as virus but contain one or more different protein part of the virus. Upon contact with healthy cell, EVs can transfer its content that make healthy cell more prone to new infection. The EVs released from an infected cell may alter the immune response as compared to the other EVs derived from a healthy cell. Still there is no clear literatures available about the involvement of EVs in COVID-19 virus infection.

The most common EV structure contains a verity of tetraspanin protein, which may facilitate the coronavirus attachment to the cell (Charrin et al. 2009). A recent study was performed on patients infected with respiratory viruses such as coronavirus and rhinovirus and isolated EVs from the serum of these patients. Interestingly, they found that these EVs contain a variety of protein inside including the viral antigen and lung self-antigen (Gunasekaran et al. 2020). This study provides an evidence of a possible link between EV-facilitated viral infection and eliciting the immune response in the body. The spike protein present on the surface of SARS-CoV has a strong affinity towards human ACE2 receptor. Recent studies have shown a close resemblance in the spike protein of SARS-CoV and SARS-CoV-2. Further, the affinity between SARS-CoV-2 and human ACE2 is much stronger than with SARS-CoV, which leads to higher infection rate with SARS-CoV-2. An in vivo research has shown the ability of EVs to transfer the ACE2 receptor to the target cell, (Wang et al. 2020), which can become a functional receptor in the recipient cells and provides a supportive evidence of the role of EVs in SARS-CoV-2 infection and spread. EVs also exhibit the surface presence of major histocompatibility complex class I and II, which suggests the possible role of EV in antigen presentation.

\section{Extracellular Vesicles in Smoking-induced COVID-19 Pathogenesis}

After evaluating a comprehensive set of transcriptomic data, a study found an association of tobacco smoking with increased gene expression of ACE2 receptors (Cai et al. 2020). This study indicated smoking as one of the risk factors for COVID-19 by affecting ACE2 expression. Also, they reported an extensive hyperplasia in goblet cells that mainly carrying ACE2 gene. It is reported that goblet cell hyperplasia and epithelial inflammation in peripheral airways is profound in smokers (Saetta et al. 2000). The contribution of several genes to the vulnerability to cigarette-smoking has also been reported, such as nicotine-metabolizing enzymes (CYP2A6) and proinflammatory cytokines and chemokines. In our earlier studies, we provided the evidence of altered levels of cytokines and chemokines as well as other proteins in EVs derived from the plasma of HIV-infected cigarette smokers (Kodidela et al. 2018, 2020b). In addition, exposure to cigarette smoke condensate increases oxidative stress and HIV replication in human monocytic cells (U937 and U1) (Haque et al. $2020 \mathrm{~b}$ ). Production of proinflammatory cytokines and chemokines are associated with smoking tobacco and pathogenesis of COVID-19, which causes lungs damage (Kaur et al. 2020). Elevated levels of these cellular cytokines and chemokines can be packaged into EVs, circulate via plasma, and delivered to neighboring or distant recipient cells, thus participating in EV-based cell-cell communication. We previously showed that cytokines and chemokines can be differentially packaged into EVs and circulated via plasma in HIV and/or tobacco smoking individuals (Kodidela et al. 2018). 


\section{Extracellular Vesicles in Smoking-induced Renal Failure in COVID-19 Patients}

Cigarette smoking can increase the risk of renal cell carcinoma by $35 \%$ (Yuan et al. 1998). These tumors grow further by developing new blood vessels and providing oxygen and nutrition to the developing tumor thus leading to metastasize the tumor to other parts of the body. Vascular endothelial growth factor (VEGF) is the chemical signal, which directs the growth and formation of new blood vessels in the tumor. Recent studies suggest that EVs transport various proangiogenic factors such as VEGF, matrix metalloproteinases (MMPs), and microRNAs, which can further promote the angiogenesis in tumor (Baj-Krzyworzeka et al. 2006; Olejarz et al. 2020). EVs and their subtypes such as prostasomes and microvesicles stimulate angiogenesis in prostate and lung cancers (Janowska-Wieczorek et al. 2005).

Nicotine acetylcholine receptors (nAChRs), which are involved in nicotine-mediated effects, are a kind of neurotransmitter receptors and are characterized by the presence of ligand gated ion channel (Yeboah et al. 2008; Wu 2009). Among various subunits of this receptor, $\alpha 7-n A C h R$ is the most significant subunit, which is very important in mediating nicotine effect and causes renal injury (Rezonzew et al. 2012). Studies have shown the overexpression of nAChRs subunits i.e. $\alpha 7-n A C h R$ by nicotine, which stimulates mesangial cell proliferation and extracellular matrix (ECM) deposition leading to kidney pathogenesis (Jaimes et al. 2007). Nicotine worsens the condition of diabetic nephropathy in mice and can damage the kidney filters (Hua et al. 2010). Compared to nonsmokers, smokers have high chances of developing CKD, especially when it is classified as hypertensive nephropathy and diabetic nephropathy (Yacoub et al. 2010). In diabetic nephropathy condition, i.e. in high glucose condition, macrophages secreted significantly higher number of EVs as compared to normal glucose condition. These EVs are enriched in TGF- $\beta 1$ mRNA, which is avidly taken by glomerular mesangial cells in vitro and in vivo resulted in overexpression of transforming growth factor- $\beta$ (TGF$\beta 1$ ) (Zhu et al. 2019b). TGF- $\beta$ is a well-known profibrotic growth factor, which is generally activated AKI, promoting the pathways that stimulate CKD (Gewin 2019).

\section{Extracellular Vesicles as Biomarkers in Smoking-induced Kidney Disease in COVID-19 Patients}

As described above, smoking increases the risk of renal dysfunction, particularly among AA, who are disproportionately affected by CKD. Further, a metanalysis by Hansrivijit et al., which analyzed the data from 26 studies $(n=5497)$ reported that the presence of AKI increases the risk of mortality by 13-fold in patients with COVID-19 (Hansrivijit et al. 2020). Various studies have also reported that CKD was the most prevalent risk factor for severe COVID-19 worldwide (Clark et al. 2020; Nadim et al. 2020; Council and Group 2021). In addition, smoking is an independent risk factor for severe COVID-19 (Xiang et al. 2021) and can exacerbate renal failure in COVID-19 patients. However, the mechanism of these relationships is unclear, and prognostic biomarkers for the COVID-19 disease and its systemic complications are lacking. Since emerging evidence suggest that EVs and their content are functionally involved in many pathological processes, they may serve as predictors/biomarkers in smokinginduced renal failure in COVID-19 patients. Several studies have already reported that circulating EVs and their contents are associated with severity, increased comorbidities, and mortality in patients with COVID-19 (Krishnamachary et al. 2020; Rosell et al. 2020; Wu et al. 2020; Yu Fujita 2020). Recently a study has demonstrated that COVID-19 patients with kidney disease had significantly altered levels of several proteins compared to their respective controls, suggesting candidate biomarkers for kidney disease in those patients (Huang 2020). Furthermore, few proteins such as F2R, THBD, FGF23, MMP12, CSF1, and KLK6 were associated with COVID-19 and kidney disease. The same study has also reported that MMP12, VEGFD, PRLSPON1, and LEP proteins are associated with smoking and COVID19. MMP12 was found to be higher among smokers and patients with Kidney disease; therefore, it may be shared as a proinflammatory mediator between these two conditions and COVID-19. The study also suggests that there was a significant overlap in markers associated with preexisting kidney disease and hypertension, particularly FGF19. Smoking causes kidney damage through various mechanisms and one of the mechanisms is hypertension (Orth and Hallan 2008). Moreover, EVs contain FGF19 protein (Silvestro et al. 2020). Since the contents of the EVs are reported to be stable in the circulation, the levels of FGF19 in EVs can serve as a potential marker for smoking-induced renal failure in COVID 19 patients. However, given the paucity of data regarding the biomarkers for smoking-induced renal failure in COVID-19 patients, prospective studies considering the proteomic or transcriptomic profiles of EVs derived from COVID19 patients with and without smoking and kidney diseases would provide reliable biomarkers for these conditions.

\section{Extracellular Vesicles in Therapeutic Development for COVID-19 Patients Suffering from Kidney Diseases}

Due to their ability to carry and transport distinct molecular cargo, EVs have been studied for their potential as therapeutic against SARS-CoV-2 infection (Fig. 2). Recent 


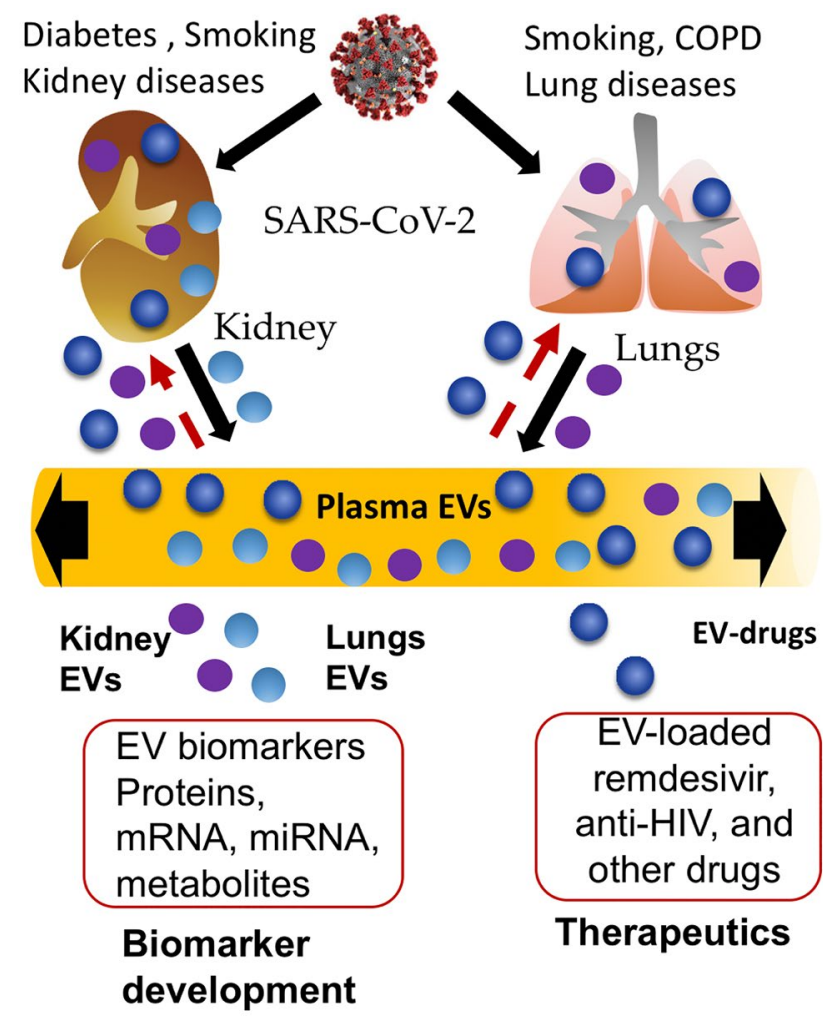

Fig. 2 Extracellular vesicle as biomarker and Therapeutics in SARS$\mathrm{CoV}-2$ induced lungs and kidney manifestation. People having underlying medical condition such as diabetes, hypertension and a habit of smoking are at higher risk of COVID-19. SARS-CoV-2 leads to extracellular vesicles mediated lungs and kidney manifestation which is exacerbated by smoking. EV contain a lot of mRNA, miRNA, protein, and metabolites and therefore can be used as a potential biomarker in COVID-19. In addition, endogenous EVs can be modulated as well as EVs can be used as drug delivery modality to enhance the therapeutic efficacy of antiretroviral drugs such as remdesivir

preclinical studies found that MSC-secretome enriched with anti-inflammatory cytokines that have been involved in tissue repair as well as immunomodulatory and antiinflammatory activity are critical for lung tissue regeneration (Bari et al. 2019), which could offer promise for EVs based therapeutics for COVID-19 and respiratory virus infections. Other than this study, there is no literature on how to target controlled release of EVs, release of EVs containing protective elements, and/or reduced packaging of toxic elements within cells that are exposed to smoking and/or SARS-CoV-2 infection. We speculate that certain compounds, e.g. nutraceuticals or other chemodietary agents, which are known to possess anti-inflammatory and anti-oxidant properties could be targeted to smoking and/or COVID-19 damaged tissue (Suzuki et al. 2009; Begum et al. 2017; Ghosh et al. 2020; Manoharan et al. 2020; Mhatre et al. 2021; Thimmulappa et al. 2021). The chemodietary agents could increase the antioxidant and anti-inflammatory levels of in the target cells, packaged in EVs, and subsequently circulated and delivered to other tissues/organs. This therapeutic approach could help reduce the damage of other organs via EV-based cell-cell communication. The other approach could be to reduce/abolish the cellular synthesis or packaging of toxic elements in EVs by using specific inhibitory agents in cells sensitive to smoking and/or COVID-19. This approach could minimize the circulation of toxic EVs released by these cells, and eventually reduce damage of distant tissues/organs via EV-based cell-cell interactions. Since these approaches are speculative, Further studies are required to access the therapeutic potential of EVs for many diseases including COVID-19 infection.

Research effort are also underway to use EVs an alternative treatment option using its novel drug delivery approach for viral diseases (Kumar et al. 2020a, b, c). Most importantly, EVs can be used in a personalized medicine approach for many patients. EVs can be isolated from a person and then loaded with the choice of drugs and again injected back into same person (Kumar et al. 2020c). This strategy would bypass the immune system, which is currently successful in cancer therapy. Some the antiviral medicine such as remdesivir, which is approved for emergency use, can be used as a cargo in the EVs, which could reduce the side effect and improve the efficacy (Kumar et al. 2020c). In addition, many anti-viral and antiretroviral drugs, especially protease inhibitors, have been studied to reduce the severity of COVID-19 pathogenesis (Siemieniuk et al. 2020). However, these drugs also cause toxicity to various organs and offtarget effects at relatively high doses. Thus, EVs have been proposed to encapsulate these drugs and deliver them by targeting SARS-CoV-2-infected cells/organs (Kumar et al. 2020c). To target the kidney cells in COVID-19 patients, these drugs can be encapsulated in EVs derived from Vero CCL-81 or Vero E6 cells using exogenous or endogenous loading method (Kumar et al. 2020c). These are kidneyderived cells and are model cell lines to study in vitro SARSCoV-2 infection (Day et al. 2021). Thus, EV obtained from these cell lines for drug delivery has the potential to directly target kidney cells and reduce off-target effects.

Furthermore, microRNAs, which can be packaged in EVs, could also be used in therapy for COVID-19. Kalarikkal and Sundaram studied a total of 260 edible nanoparticles (ENP)-derived miRNAs from various plants and identified 10 miRNAs that could specifically target SARS-CoV-2 genome. The study suggested that ENPderived miRNAs targeting SARS-CoV-2 genome has the great potential to be developed as an alternative therapy (Kalarikkal and Sundaram 2021).

In addition to utilizing EVs as delivery system, EVs have also been proposed to be utilize as vaccines (Sabanovic et al. 2021). The chimeric S protein-containing EVs have been tested as a novel protein for vaccine immunogenicity against SARS-COV-1 in mouse models (Kuate et al. 2007). Recent studies have highlighted the role of native or engineered 
EVs in the induction of $\mathrm{B}$ cell and $\mathrm{CD} 8(+) \mathrm{T}$ cell reactions against viral proteins (Qazi et al. 2009; Kanuma et al. 2017). These studies suggest that these antigen-presenting EVs can be used as a novel strategy for vaccine design, including COVID-19. EV-based vaccines can overcome some limitations of conventional vaccines such as biosafety and efficiency. Some Biotech companies are working on the development of futuristic EV-based vaccine. However, there is a paucity of data in the literature for EV-based vaccines for infectious diseases including SARS-CoV-2. Therefore, further studies are needed to establish the role of EVs in vaccines development, especially against SARS-CoV-2, which can reduce the prevalence of COVID-19-induced renal damage, especially in AA populations.

Funding The funding was obtained from the National Institute of Health grant (DA047178) and funds available from the University of Tennessee Health Science Center.

\section{Declarations}

Conflict of Interest The authors have no relevant affiliations or financial involvement with any organization or entity with a financial interest in or financial conflict with the subject matter or materials discussed in the manuscript. This includes employment, consultancies, honoraria, stock ownership or options, expert testimony, grants or patents received or pending, or royalties.

\section{References}

Albini A, Di Guardo G, Noonan DM, Lombardo M (2020) The SARS$\mathrm{CoV}-2$ receptor, $\mathrm{ACE}-2$, is expressed on many different cell types: implications for ACE-inhibitor- and angiotensin II receptor blocker-based cardiovascular therapies. Intern Emerg Med 15:759-766

Andrasfay T, Goldman N (2021) Reductions in 2020 US life expectancy due to COVID-19 and the disproportionate impact on the Black and Latino populations. Proc Natl Acad Sci U S A 118

Anguiano L, Riera M, Pascual J, Soler MJ (2017) Circulating ACE2 in Cardiovascular and Kidney Diseases. Curr Med Chem 24:3231-3241

Attaway AA, Zein J, Hatipoglu US (2020) SARS-CoV-2 infection in the COPD population is associated with increased healthcare utilization: An analysis of Cleveland clinic's COVID-19 registry. EClinicalMedicine 26:100515

Baj-Krzyworzeka M, Szatanek R, Weglarczyk K, Baran J, Urbanowicz B, Branski P, Ratajczak MZ, Zembala M (2006) Tumour-derived microvesicles carry several surface determinants and mRNA of tumour cells and transfer some of these determinants to monocytes. Cancer Immunol Immunother 55:808-818

Bari E, Ferrarotti I, Torre ML, Corsico AG, Perteghella S (2019) Mesenchymal stem/stromal cell secretome for lung regeneration: The long way through "pharmaceuticalization" for the best formulation. J Control Release 309:11-24

Begum MS, Saradamma B, Reddy VD, Padmavathi P, Maturu P, babu Ellutla N, Thippannagari L, Varadacharyulu NC (2017) Influence of green tea consumption on cigarette smoking-induced biochemical changes in plasma and blood. Clin Nutr Exp 16:1-12
Benedikter BJ, Volgers C, van Eijck PH, Wouters EFM, Savelkoul PHM, Reynaert NL, Haenen G, Rohde GGU, Weseler AR, Stassen FRM (2017) Cigarette smoke extract induced exosome release is mediated by depletion of exofacial thiols and can be inhibited by thiol-antioxidants. Free Radic Biol Med 108:334-344

Benedikter BJ, Bouwman FG, Heinzmann ACA, Vajen T, Mariman EC, Wouters EFM, Savelkoul PHM, Koenen RR, Rohde GGU, van Oerle R, Spronk HM, Stassen FRM (2019) Proteomic analysis reveals procoagulant properties of cigarette smokeinduced extracellular vesicles. J Extracell Vesicles 8:1585163

Bland AR, Roiser JP, Mehta MA, Sahakian BJ, Robbins TW, Elliott $\mathrm{R}$ (2021) The impact of COVID-19 social isolation on aspects of emotional and social cognition. Cogn Emot:1-10.

Brashier BB, Kodgule R (2012) Risk factors and pathophysiology of chronic obstructive pulmonary disease (COPD). J Assoc Physicians India 60(Suppl):17-21

Bruschi M, Granata S, Santucci L, Candiano G, Fabris A, Antonucci N, Petretto A, Bartolucci M, Del Zotto G, Antonini F, Ghiggeri GM, Lupo A, Gambaro G, Zaza G (2019) Proteomic Analysis of Urinary Microvesicles and Exosomes in Medullary Sponge Kidney Disease and Autosomal Dominant Polycystic Kidney Disease. Clin J Am Soc Nephrol 14:834-843

Cai G, Bosse Y, Xiao F, Kheradmand F, Amos CI (2020) Tobacco Smoking Increases the Lung Gene Expression of ACE2, the Receptor of SARS-CoV-2. Am J Respir Crit Care Med 201:1557-1559

CDC (2017) African American Health. https://www.cdc.gov/vitalsigns/ aahealth/index.html. Accessed 05 July 2021

CDC (2020) Tobacco-Related Mortality. https://www.cdc.gov/ tobacco/data_statistics/fact_sheets/health_effects/tobacco_ related_mortality/index.htm. Accessed 05 July 2021

CDC (2021a) African Americans and Tobacco Use. https://www.cdc. gov/tobacco/disparities/african-americans/index.htm. Accessed 05 July 2021

CDC (2021b) Risk for COVID-19 Infection, Hospitalization, and Death By Race/Ethnicity. https://www.cdc.gov/coronavirus/ 2019-ncov/covid-data/investigations-discovery/hospitalizationdeath-by-race-ethnicity.html. Accessed 05 July 2021

CDC (2021c) Smoking And Overall Health. https://www.cdc.gov/ tobacco/data_statistics/sgr/50th-anniversary/pdfs/fs_smoking _ overall_health_508.pdf. Accessed 05 July 2021

Charrin S, le Naour F, Silvie O, Milhiet PE, Boucheix C, Rubinstein E (2009) Lateral organization of membrane proteins: tetraspanins spin their web. Biochem J 420:133-154

Chatila WM, Wynkoop WA, Vance G, Criner GJ (2004) Smoking patterns in African Americans and whites with advanced COPD. Chest 125:15-21

Choi HS, Han KD, Oh TR, Kim CS, Bae EH, Ma SK, Kim SW (2019) Smoking and risk of incident end-stage kidney disease in general population: A Nationwide Population-based Cohort Study from Korea. Sci Rep 9:19511

Clark A, Jit M, Warren-Gash C, Guthrie B, Wang HHX, Mercer SW, Sanderson C, McKee M, Troeger C, Ong KL, Checchi F, Perel P, Joseph S, Gibbs HP, Banerjee A, Eggo RM, Centre for the Mathematical Modelling of Infectious Diseases C-wg, (2020) Global, regional, and national estimates of the population at increased risk of severe COVID-19 due to underlying health conditions in 2020: a modelling study. Lancet Glob Health 8:e1003-e1017

Colombo M, Raposo G, Thery C (2014) Biogenesis, secretion, and intercellular interactions of exosomes and other extracellular vesicles. Annu Rev Cell Dev Biol 30:255-289

Council E-E, Group EW (2021) Chronic kidney disease is a key risk factor for severe COVID-19: a call to action by the ERA-EDTA. Nephrol Dial Transplant 36:87-94 
Day CJ, Bailly B, Guillon P, Dirr L, Jen FE, Spillings BL, Mak J, von Itzstein M, Haselhorst T, Jennings MP (2021) Multidisciplinary Approaches Identify Compounds that Bind to Human ACE2 or SARS-CoV-2 Spike Protein as Candidates to Block SARS-CoV2-ACE2 Receptor Interactions. mBio 12

De Palma G, Sallustio F, Curci C, Galleggiante V, Rutigliano M, Serino G, Ditonno P, Battaglia M, Schena FP (2016) The Three-Gene Signature in Urinary Extracellular Vesicles from Patients with Clear Cell Renal Cell Carcinoma. J Cancer 7:1960-1967

Deane JA, Verghese E, Martelotto LG, Cain JE, Galtseva A, Rosenblum ND, Watkins DN, Ricardo SD (2013) Visualizing Renal Primary Cilia Nephrology (carlton) 18:161-168

Deatherage BL, Cookson BT (2012) Membrane vesicle release in bacteria, eukaryotes, and archaea: a conserved yet underappreciated aspect of microbial life. Infect Immun 80:1948-1957

Dimuccio V, Ranghino A, Pratico Barbato L, Fop F, Biancone L, Camussi G, Bussolati B (2014) Urinary CD133+ extracellular vesicles are decreased in kidney transplanted patients with slow graft function and vascular damage. PLoS One 9:e104490

Donate PB, Alves de Lima K, Peres RS, Almeida F, Fukada SY, Silva TA, Nascimento DC, Cecilio NT, Talbot J, Oliveira RD, Passos GA, Alves-Filho JC, Cunha TM, Louzada-Junior P, Liew FY, Cunha FQ (2021) Cigarette smoke induces miR-132 in Th17 cells that enhance osteoclastogenesis in inflammatory arthritis. Proc Natl Acad Sci U S A 118

Doyle LM, Wang MZ (2019) Overview of Extracellular Vesicles, Their Origin, Composition, Purpose, and Methods for Exosome Isolation and Analysis. Cells 8:727

Esteva-Font C, Guillen-Gomez E, Diaz JM, Guirado L, Facundo C, Ars E, Ballarin JA, Fernandez-Llama P (2014) Renal sodium transporters are increased in urinary exosomes of cyclosporinetreated kidney transplant patients. Am J Nephrol 39:528-535

Feller D, Kun J, Ruzsics I, Rapp J, Sarosi V, Kvell K, Helyes Z, Pongracz JE (2018) Cigarette smoke-induced pulmonary inflammation becomes systemic by circulating extracellular vesicles containing Wnt5a and inflammatory cytokines. Front Immunol 9:1724

Ferraro PM, Bonello M, Frigo AC, D’Addessi A, Sturniolo A, Gambaro G (2011) Cadmium exposure and kidney stone formation in the general population-an analysis of the National Health and Nutrition Examination Survey III data. J Endourol 25:875-880

Fisher M, Neugarten J, Bellin E, Yunes M, Stahl L, Johns TS, Abramowitz MK, Levy R, Kumar N, Mokrzycki MH, Coco M, Dominguez M, Prudhvi K, Golestaneh L (2020) AKI in Hospitalized Patients with and without COVID-19: A Comparison Study. J Am Soc Nephrol 31:2145-2157

Flook M, Jackson C, Vasileiou E, Simpson CR, Muckian MD, Agrawal U, McCowan C, Jia Y, Murray JLK, Ritchie LD, Robertson C, Stock SJ, Wang X, Woolhouse MEJ, Sheikh A, Stagg HR (2021) Informing the public health response to COVID-19: a systematic review of risk factors for disease, severity, and mortality. BMC Infect Dis 21:342

Fujita Y, Araya J, Ito S, Kobayashi K, Kosaka N, Yoshioka Y, Kadota T, Hara H, Kuwano K, Ochiya T (2015) Suppression of autophagy by extracellular vesicles promotes myofibroblast differentiation in COPD pathogenesis. J Extracell Vesicles 4:28388

Gabarre P, Dumas G, Dupont T, Darmon M, Azoulay E, Zafrani L (2020) Acute kidney injury in critically ill patients with COVID19. Intensive Care Med 46:1339-1348

Gaiha SM, Lempert LK, Halpern-Felsher B (2020a) Underage youth and young adult e-cigarette use and access before and during the coronavirus disease 2019 pandemic. JAMA Netw Open 3:e2027572

Gaiha SM, Cheng J, Halpern-Felsher B (2020) Association between youth smoking, electronic cigarette use, and COVID-19. J Adolesc Health 67:519-523
Gaillard F, Ismael S, Sannier A, Tarhini H, Volpe T, Greze C, Verpont MC, Zouhry I, Rioux C, Lescure FX, Buob D, Daugas E (2020) Tubuloreticular inclusions in COVID-19-related collapsing glomerulopathy. Kidney Int 98:241

Garg S, Kim L, Whitaker M, O'Halloran A, Cummings C, Holstein R, Prill M, Chai SJ, Kirley PD, Alden NB, Kawasaki B, YouseyHindeK NL, Anderson EJ, Openo KP, Weigel A, Monroe ML, Ryan P, Henderson J, Kim S, Como-Sabetti K, Lynfield R, Sosin D, Torres S, Muse A, Bennett NM, Billing L, Sutton M, West N, Schaffner W, Talbot HK, Aquino C, George A, Budd A, Brammer L, Langley G, Hall AJ, Fry A (2020) Hospitalization Rates and Characteristics of Patients Hospitalized with Laboratory-Confirmed Coronavirus Disease 2019 - COVIDNET, 14 States, March 1-30, 2020. MMWR Morb Mortal Wkly Rep 69:458-464

Gewin LS (2019) Transforming Growth Factor-beta in the Acute Kidney Injury to Chronic Kidney Disease Transition. Nephron 143:154-157

Ghosh R, Chakraborty A, Biswas A, Chowdhuri S (2020) Evaluation of green tea polyphenols as novel corona virus (SARS CoV-2) main protease (Mpro) inhibitors - an in silico docking and molecular dynamics simulation study. J Biomol Struct Dyn $1-13$

Gold JAW, Rossen LM, Ahmad FB, Sutton P, Li Z, Salvatore PP, Coyle JP, DeCuir J, Baack BN, Durant TM, Dominguez KL, Henley SJ, Annor FB, Fuld J, Dee DL, Bhattarai A, Jackson BR (2020) Race, ethnicity, and age trends in persons who died from COVID-19-United States, May-August 2020. MMWR Morb Mortal Wkly Rep 69:1517-1521

Gunasekaran M, Bansal S, Ravichandran R, Sharma M, Perincheri S, Rodriguez F, Hachem R, Fisher CE, Limaye AP, Omar A, Smith MA, Bremner RM, Mohanakumar T (2020) Respiratory viral infection in lung transplantation induces exosomes that trigger chronic rejection. J Heart Lung Transplant 39:379-388

Gur RE, White LK, Waller R, Barzilay R, Moore TM, Kornfield S, Njoroge WFM, Duncan AF, Chaiyachati BH, Parish-Morris J, Maayan L, Himes MM, Laney N, Simonette K, Riis V, Elovitz MA (2020) The disproportionate burden of the COVID-19 pandemic among pregnant black women. Psychiatry Res 293:113475

Halimi JM, Mimran A (2000) Renal effects of smoking: potential mechanisms and perspectives. Nephrol Dial Transplant 15:938-940

Halimi JM, Giraudeau B, Vol S, Caces E, Nivet H, Lebranchu Y, Tichet J (2000) Effects of current smoking and smoking discontinuation on renal function and proteinuria in the general population. Kidney Int 58:1285-1292

Hall ME, Wang W, Okhomina V, Agarwal M, Hall JE, Dreisbach AW, Juncos LA, Winniford MD, Payne TJ, Robertson RM, Bhatnagar A, Young BA (2016) Cigarette smoking and chronic kidney disease in African Americans in the Jackson Heart Study. J Am Heart Assoc 5

Hansrivijit P, Qian C, Boonpheng B, Thongprayoon C, Vallabhajosyula S, Cheungpasitporn W, Ghahramani N (2020) Incidence of acute kidney injury and its association with mortality in patients with COVID-19: a meta-analysis. J Investig Med 68:1261-1270

Haque S, Kodidela S, Sinha N, Kumar P, Cory TJ, Kumar S (2020a) Differential packaging of inflammatory cytokines/ chemokines and oxidative stress modulators in U937 and U1 macrophages-derived extracellular vesicles upon exposure to tobacco constituents. PLoS One 15:e0233054

Haque S, Kodidela S, Gerth K, Hatami E, Verma N, Kumar S (2020b) Extracellular vesicles in smoking-mediated HIV pathogenesis and their potential role in biomarker discovery and therapeutic interventions. Cells 9

Haroun MK, Jaar BG, Hoffman SC, Comstock GW, Klag MJ, Coresh J (2003) Risk factors for chronic kidney disease: a prospective study of 23,534 men and women in Washington County, Maryland. J Am Soc Nephrol 14:2934-2941 
Hastie CE, Mackay DF, Ho F, Celis-Morales CA, Katikireddi SV, Niedzwiedz CL, Jani BD, Welsh P, Mair FS, Gray SR, O’Donnell CA, Gill JM, Sattar N, Pell JP (2020) Vitamin D concentrations and COVID-19 infection in UK Biobank. Diabetes Metab Syndr 14:561-565

He C, Zheng S, Luo Y, Wang B (2018) Exosome Theranostics: Biology and Translational Medicine. Theranostics 8:237-255

Hirsch JS, Ng JH, Ross DW, Sharma P, Shah HH, Barnett RL, Hazzan AD, Fishbane S, Jhaveri KD, Northwell C-RC, Northwell Nephrology C-RC (2020) Acute kidney injury in patients hospitalized with COVID-19. Kidney Int 98:209-218

Hogan MC, Manganelli L, Woollard JR, Masyuk AI, Masyuk TV, Tammachote R, Huang BQ, Leontovich AA, Beito TG, Madden BJ, Charlesworth MC, Torres VE, LaRusso NF, Harris PC, Ward CJ (2009) Characterization of PKD protein-positive exosome-like vesicles. J Am Soc Nephrol 20:278-288

Hogan MC, Bakeberg JL, Gainullin VG, Irazabal MV, Harmon AJ, Lieske JC, Charlesworth MC, Johnson KL, Madden BJ, Zenka RM, McCormick DJ, Sundsbak JL, Heyer CM, Torres VE, Harris PC, Ward CJ (2015) Identification of Biomarkers for PKD1 Using Urinary Exosomes. J Am Soc Nephrol 26:1661-1670

Hua P, Feng W, Ji S, Raij L, Jaimes EA (2010) Nicotine worsens the severity of nephropathy in diabetic mice: implications for the progression of kidney disease in smokers. Am J Physiol Renal Physiol 299:F732-739

Huang J (2020) Comparing biomarkers for COVID-19 disease with commonly associated preexisting conditions and complications. MedRxiV

Ichii O, Otsuka-Kanazawa S, Horino T, Kimura J, Nakamura T, Matsumoto M, Toi M, Kon Y (2014) Decreased miR-26a expression correlates with the progression of podocyte injury in autoimmune glomerulonephritis. PLoS One 9:e110383

Jaimes EA, Tian RX, Raij L (2007) Nicotine: the link between cigarette smoking and the progression of renal injury? Am J Physiol Heart Circ Physiol 292:H76-82

Janowska-Wieczorek A, Wysoczynski M, Kijowski J, MarquezCurtis L, Machalinski B, Ratajczak J, Ratajczak MZ (2005) Microvesicles derived from activated platelets induce metastasis and angiogenesis in lung cancer. Int J Cancer 113:752-760

Jones P, Karim Sulaiman S, Gamage KN, Tokas T, Jamnadass E, Somani BK (2021) Do Lifestyle Factors Including Smoking, Alcohol, and Exercise Impact Your Risk of Developing Kidney Stone Disease? Outcomes of a Systematic Review. J Endourol 35:1-7

Kalarikkal SP, Sundaram GM (2021) Edible plant-derived exosomal microRNAs: Exploiting a cross-kingdom regulatory mechanism for targeting SARS-CoV-2. 414:115425

Kanuma T, Yamamoto T, Kobiyama K, Moriishi E, Masuta Y, Kusakabe T, Ozasa K, Kuroda E, Jounai N, Ishii KJ (2017) CD63-Mediated Antigen Delivery into Extracellular Vesicles via DNA Vaccination Results in Robust CD8(+) T Cell Responses. J Immunol 198:4707-4715

Kaur G, Lungarella G, Rahman I (2020) SARS-CoV-2 COVID-19 susceptibility and lung inflammatory storm by smoking and vaping. J Inflamm (lond) 17:21

Kerr DMI, Brooksbank KJM, Taylor RG, Pinel K, Rios FJ, Touyz RM, Delles C (2019) Acute effects of electronic and tobacco cigarettes on vascular and respiratory function in healthy volunteers: a cross-over study. J Hypertens 37:154-166

King CC, Piper ME, Gepner AD, Fiore MC, Baker TB, Stein JH (2017) Longitudinal Impact of Smoking and Smoking Cessation on Inflammatory Markers of Cardiovascular Disease Risk. Arterioscler Thromb Vasc Biol 37:374-379

Kissling S, Rotman S, Gerber C, Halfon M, Lamoth F, Comte D, Lhopitallier L, Sadallah S, Fakhouri F (2020) Collapsing glomerulopathy in a COVID-19 patient. Kidney Int 98:228-231
Klag MJ, Whelton PK, Randall BL, Neaton JD, Brancati FL, Stamler $\mathbf{J}$ (1997) End-stage renal disease in African-American and white men. 16-year MRFIT findings. JAMA 277:1293-1298

Kodidela S, Kumar A, Gerth K, Kumar S, Walker C (2020a) Lessons Learned from Health Disparities Among African Americans in The HIV Epidemic: What to Expect for COVID-19 and Potential Approaches to Mitigate Health Disparity. Emerg Infect Dis Diag J: EIDDJ-100021. 2020;2(03)

Kodidela S, Ranjit S, Sinha N, McArthur C, Kumar A, Kumar S (2018) Cytokine profiling of exosomes derived from the plasma of HIV-infected alcohol drinkers and cigarette smokers. PLoS One 13:e0201144

Kodidela S, Wang Y, Patters BJ, Gong Y, Sinha N, Ranjit S, Gerth K, Haque S, Cory T, McArthur C, Kumar A, Wan JY, Kumar S (2020b) Proteomic Profiling of Exosomes Derived from Plasma of HIV-Infected Alcohol Drinkers and Cigarette Smokers. J Neuroimmune Pharmacol 15:501-519

Kooman JP, van der Sande FM (2020) COVID-19 in ESRD and Acute Kidney Injury. Blood Purif:1-11

Krishnamachary B, Cook C, Spikes L, Chalise P, Dhillon NK (2020) The Potential Role of Extracellular Vesicles in COVID-19 Associated Endothelial injury and Pro-inflammation. medRxiv

Kuate S, Cinatl J, Doerr HW, Uberla K (2007) Exosomal vaccines containing the S protein of the SARS coronavirus induce high levels of neutralizing antibodies. Virology 362:26-37

Kumar A, Kodidela S, Tadrous E, Cory TJ, Walker CM, Smith AM, Mukherjee A, Kumar S (2020a) Extracellular vesicles in viral replication and pathogenesis and their potential role in therapeutic intervention. Viruses 12

Kumar A, Zhou L, Zhi K, Raji B, Pernell S, Tadrous E, Kodidela S, Nookala A, Kochat H, Kumar S (2020b) Challenges in biomaterialbased drug delivery approach for the treatment of neurodegenerative diseases: Opportunities for extracellular vesicles. Int J Mol Sci 22

Kumar P, Zadjali F, Yao Y, Siroky B, Astrinidis A, Gross KW, Bissler JJ (2021a) Tsc Gene Locus Disruption and Differences in Renal Epithelial Extracellular Vesicles. Front Physiol

Kumar P, Zadjali F, Yao Y, Johnson D, Siroky B, Astrinidis A, Vogel P, Gross KW, Bissler JJ (2021b) Tsc2 mutation induces renal tubular cell nonautonomous disease. Genes \& Diseases

Kumar S, Zhi K, Mukherji A, Gerth K (2020c) Repurposing Antiviral Protease Inhibitors Using Extracellular Vesicles for Potential Therapy of COVID-19. Viruses 12

Kwon SH (2019) Extracellular vesicles in renal physiology and clinical applications for renal disease. Korean J Intern Med 34:470-479

Larsen CP, Bourne TD, Wilson JD, Saqqa O, Sharshir MA (2020) Collapsing glomerulopathy in a patient with COVID-19. Kidney Int Rep 5:935-939

Leung JM, Yang CX, Sin DD (2020) COVID-19 and nicotine as a mediator of ACE-2. Eur Respir J 55

Li CJ, Liu Y, Chen Y, Yu D, Williams KJ, Liu ML (2013) Novel proteolytic microvesicles released from human macrophages after exposure to tobacco smoke. Am J Pathol 182:1552-1562

Li NC, Thadhani RI, Reviriego-Mendoza M, Larkin JW, Maddux FW, Ofsthun NJ (2018) Association of smoking status with mortality and hospitalization in hemodialysis patients. Am J Kidney Dis 72:673-681

Lim MA, Pranata R, Huang I, Yonas E, Soeroto AY, Supriyadi R (2020) Multiorgan Failure With Emphasis on Acute Kidney Injury and Severity of COVID-19: Systematic Review and MetaAnalysis. Can J Kidney Health Dis 7:2054358120938573

Lopes-Pacheco M, Silva PL, Cruz FF, Battaglini D, Robba C, Pelosi P, Morales MM, Caruso Neves C, Rocco PRM (2021) Pathogenesis of multiple organ injury in COVID-19 and potential therapeutic strategies. Front Physiol 12:593223 
Magayr TA, Song X, Streets AJ, Vergoz L, Chang L, Valluru MK, Yap HL, Lannoy M, Haghighi A, Simms RJ, Tam FWK, Pei Y, Ong ACM (2020) Global microRNA profiling in human urinary exosomes reveals novel disease biomarkers and cellular pathways for autosomal dominant polycystic kidney disease. Kidney Int 98:420-435

Mahase E (2020) Covid-19: death rate is $0.66 \%$ and increases with age, study estimates. BMJ 369:m1327

Manoharan Y, Haridas V, Vasanthakumar KC, Muthu S, Thavoorullah FF, Shetty P (2020) Curcumin: a Wonder Drug as a Preventive Measure for COVID19 Management. Indian J Clin Biochem 35:373-375

Martinez-Rojas MA, Vega-Vega O, Bobadilla NA (2020) Is the kidney a target of SARS-CoV-2? Am J Physiol Renal Physiol 318:F1454-F1462

Mhatre S, Srivastava T, Naik S, Patravale V (2021) Antiviral activity of green tea and black tea polyphenols in prophylaxis and treatment of COVID-19: A review. Phytomedicine 85:153286

Miller V (2021) COVID-19 surveillance and Black American substance use disorder: An examination of data and policy. J Subst Abuse Treat 123:108243

Mobarrez F, Antoniewicz L, Bosson JA, Kuhl J, Pisetsky DS, Lundback M (2014) The effects of smoking on levels of endothelial progenitor cells and microparticles in the blood of healthy volunteers. PLoS One 9:e90314

Moon HG, Kim SH, Gao J, Quan T, Qin Z, Osorio JC, Rosas IO, Wu M, Tesfaigzi Y, Jin Y (2014) CCN1 secretion and cleavage regulate the lung epithelial cell functions after cigarette smoke. Am J Physiol Lung Cell Mol Physiol 307:L326-337

Moon PG, Lee JE, You S, Kim TK, Cho JH, Kim IS, Kwon TH, Kim CD, Park SH, Hwang D, Kim YL, Baek MC (2011) Proteomic analysis of urinary exosomes from patients of early IgA nephropathy and thin basement membrane nephropathy. Proteomics 11:2459-2475

Mousavi Movahed SM, Akhavizadegan H, Dolatkhani F, Nejadghaderi SA, Aghajani F, Faghir Gangi M, Ghazi Z, Ghasemi H (2021) Different incidences of acute kidney injury (AKI) and outcomes in COVID-19 patients with and without non-azithromycin antibiotics: A retrospective study. J Med Virol

Mulcahy LA, Pink RC, Carter DR (2014) Routes and mechanisms of extracellular vesicle uptake. J Extracell Vesicles 3

Nadim MK et al (2020) COVID-19-associated acute kidney injury: consensus report of the 25th Acute Disease Quality Initiative (ADQI) Workgroup. Nat Rev Nephrol 16:747-764

O'Neill CP, Gilligan KE, Dwyer RM (2019) Role of extracellular vesicles $(\mathrm{EVs})$ in cell stress response and resistance to cancer therapy. Cancers (Basel) 11

Obinna DN (2021) Essential and undervalued: health disparities of African American women in the COVID-19 era. Ethn Health 26:68-79

Olejarz W, Kubiak-Tomaszewska G, Chrzanowska A, Lorenc T (2020) Exosomes in angiogenesis and anti-angiogenic therapy in cancers.. Int J Mol Sci 21

Orth SR (2000) Smoking-a renal risk factor. Nephron 86:12-26

Orth SR, Hallan SI (2008) Smoking: a risk factor for progression of chronic kidney disease and for cardiovascular morbidity and mortality in renal patients-absence of evidence or evidence of absence? Clin J Am Soc Nephrol 3:226-236

Paolicelli RC, Bergamini G, Rajendran L (2019) Cell-to-cell communication by extracellular vesicles: focus on microglia. Neuroscience 405:148-157

Pi-Sunyer FX (1990) Obesity and diabetes in blacks. Diabetes Care 13:1144-1149

Pocsfalvi G, Raj DA, Fiume I, Vilasi A, Trepiccione F, Capasso G (2015) Urinary extracellular vesicles as reservoirs of altered proteins during the pathogenesis of polycystic kidney disease. Proteomics Clin Appl 9:552-567

Pocsfalvi G, Mammadova R, Ramos Juarez AP, Bokka R, Trepiccione F, Capasso G (2020) COVID-19 and Extracellular Vesicles: An Intriguing Interplay. Kidney Blood Press Res 45:661-670

Pranata R, Supriyadi R, Huang I, Permana H, Lim MA, Yonas E, Soetedjo NNM, Lukito AA (2020) The Association Between Chronic Kidney Disease and New Onset Renal Replacement Therapy on the Outcome of COVID-19 Patients: A Meta-analysis. Clin Med Insights Circ Respir Pulm Med 14:1179548420959165

Qazi KR, Gehrmann U, Domange Jordo E, Karlsson MC, Gabrielsson S (2009) Antigen-loaded exosomes alone induce Th1-type memory through a B-cell-dependent mechanism. Blood 113:2673-2683

Raimondo F, Morosi L, Corbetta S, Chinello C, Brambilla P, Della Mina P, Villa A, Albo G, Battaglia C, Bosari S, Magni F, Pitto M (2013) Differential protein profiling of renal cell carcinoma urinary exosomes. Mol Biosyst 9:1220-1233

Rezonzew G, Chumley P, Feng W, Hua P, Siegal GP, Jaimes EA (2012) Nicotine exposure and the progression of chronic kidney disease: role of the alpha7-nicotinic acetylcholine receptor. Am J Physiol Renal Physiol 303:F304-312

Richter PA, Bishop EE, Wang J, Swahn MH (2009) Tobacco smoke exposure and levels of urinary metals in the U.S. youth and adult population: the National Health and Nutrition Examination Survey (NHANES) 1999-2004. Int J Environ Res Public Health 6:1930-1946

Rosell A, Havervall S, von Meijenfeldt F, Hisada Y, Aguilera K, Grover SP, Lisman T, Mackman N, Thalin C (2020) Patients with COVID-19 have elevated levels of circulating extracellular vesicle tissue factor activity that is associated with severity and mortality. Arterioscler Thromb Vasc Biol: ATVBAHA120315547

Russo P, Bonassi S, Giacconi R, Malavolta M, Tomino C, Maggi F (2020) COVID-19 and smoking: is nicotine the hidden link? Eur Respir $\mathrm{J} 55$

Sabanovic B, Piva F, Cecati M, Giulietti M (2021) Promising extracellular vesicle-based vaccines against viruses, including SARSCoV-2. Biology (Basel) 10

Saetta M, Turato G, Baraldo S, Zanin A, Braccioni F, Mapp CE, Maestrelli P, Cavallesco G, Papi A, Fabbri LM (2000) Goblet cell hyperplasia and epithelial inflammation in peripheral airways of smokers with both symptoms of chronic bronchitis and chronic airflow limitation. Am J Respir Crit Care Med 161:1016-1021

Sanyaolu A, Okorie C, Marinkovic A, Patidar R, Younis K, Desai P, Hosein Z, Padda I, Mangat J, Altaf M (2020) Comorbidity and its Impact on Patients with COVID-19. SN Compr Clin Med:1-8

Segura E, Nicco C, Lombard B, Veron P, Raposo G, Batteux F, Amigorena $S$, Thery C (2005) ICAM-1 on exosomes from mature dendritic cells is critical for efficient naive T-cell priming. Blood 106:216-223

Serban KA, Rezania S, Petrusca DN, Poirier C, Cao D, Justice MJ, Patel M, Tsvetkova I, Kamocki K, Mikosz A, Schweitzer KS, Jacobson S, Cardoso A, Carlesso N, Hubbard WC, Kechris K, Dragnea B, Berdyshev EV, McClintock J, Petrache I (2016) Structural and functional characterization of endothelial microparticles released by cigarette smoke. Sci Rep 6:31596

Siemieniuk RA et al. (2020) Drug treatments for covid-19: living systematic review and network meta-analysis. BMJ 370:m2980

Silvestro S, Chiricosta L, Gugliandolo A, Pizzicannella J, Diomede F, Bramanti P, Trubiani O, Mazzon E (2020) Extracellular vesicles derived from human gingival mesenchymal stem cells: a transcriptomic analysis. Genes (Basel) 11

Snowden LR, Snowden JM (2021) Coronavirus Trauma and African Americans' Mental Health: Seizing Opportunities for Transformational Change. Int J Environ Res Public Health 18 
Song B, Dai D, Liu S, Zhu Z, Ding F, Zhu J, Zhang R (2021) Optimal timing of coronary angiograms for patients with chronic kidney disease: association between the duration of kidney dysfunction and SYNTAX scores. Ren Fail 43:307-312

Stasi A, Castellano G, Ranieri E, Infante B, Stallone G, Gesualdo L, Netti GS (2020) SARS-CoV-2 and Viral Sepsis: Immune Dysfunction and Implications in Kidney Failure. J Clin Med 9

Stojanovic D, Nikic D, Lazarevic K (2004) The level of nickel in smoker's blood and urine. Cent Eur J Public Health 12:187-189

Su H, Yang M, Wan C, Yi LX, Tang F, Zhu HY, Yi F, Yang HC, Fogo AB, Nie X, Zhang C (2020) Renal histopathological analysis of 26 postmortem findings of patients with COVID19 in China. Kidney Int 98:219-227

Sundar IK, Li D, Rahman I (2019) Small RNA-sequence analysis of plasma-derived extracellular vesicle miRNAs in smokers and patients with chronic obstructive pulmonary disease as circulating biomarkers. J Extracell Vesicles 8:1684816

Suzuki M, Betsuyaku T, Ito Y, Nagai K, Odajima N, Moriyama C, Nasuhara Y, Nishimura M (2009) Curcumin attenuates elastaseand cigarette smoke-induced pulmonary emphysema in mice. Am J Physiol Lung Cell Mol Physiol 296:L614-623

Thimmulappa RK, Mudnakudu-Nagaraju KK, Shivamallu C, Subramaniam KJT, Radhakrishnan A, Bhojraj S, Kuppusamy G (2021) Antiviral and immunomodulatory activity of curcumin: A case for prophylactic therapy for COVID-19. Heliyon 7:e06350

Thomashow MA, Shimbo D, Parikh MA, Hoffman EA, Vogel-Claussen J, Hueper K, Fu J, Liu CY, Bluemke DA, Ventetuolo CE, Doyle MF, Barr RG (2013) Endothelial microparticles in mild chronic obstructive pulmonary disease and emphysema. The Multi-Ethnic Study of Atherosclerosis Chronic Obstructive Pulmonary Disease study. Am J Respir Crit Care Med 188:60-68

Tsai J, Homa DM, Gentzke AS, Mahoney M, Sharapova SR, Sosnoff CS, Caron KT, Wang L, Melstrom PC, Trivers KF (2018) Exposure to Secondhand Smoke Among Nonsmokers - United States, 19882014. MMWR Morb Mortal Wkly Rep 67:1342-1346

United States Renal Data System (2020) USRDS Annual Data Report: Epidemiology of kidney disease in the United States. National Institutes of Health, National Institute of Diabetes and Digestive and Kidney Diseases. https://adr.usrds.org/2020. Accessed 6 May 2021

van Niel G, D'Angelo G, Raposo G (2018) Shedding light on the cell biology of extracellular vesicles. Nat Rev Mol Cell Biol 19:213-228

Virdis A, Giannarelli C, Neves MF, Taddei S, Ghiadoni L (2010) Cigarette smoking and hypertension. Curr Pharm Des 16:2518-2525

Wang J, Chen S, Bihl J (2020) Exosome-Mediated Transfer of ACE2 (Angiotensin-Converting Enzyme 2) from Endothelial Progenitor Cells Promotes Survival and Function of Endothelial Cell. Oxid Med Cell Longev 2020:4213541

Wang QQ, Kaelber DC, Xu R, Volkow ND (2021) COVID-19 risk and outcomes in patients with substance use disorders: analyses from electronic health records in the United States. Mol Psychiatry 26:30-39

Williamson EJ et al (2020) Factors associated with COVID-19-related death using OpenSAFELY. Nature 584:430-436

Winniford MD (1990) Smoking and cardiovascular function. J Hypertens Suppl 8:S17-23

Wu AHB, Zhang Y, Webber R (2020) Extracellular vesicles released in blood of COVID-19 patients: mechanism for detection of cardiac troponin after myocardial injury? Biomarkers 25:613-615

Wu F, Yin Z, Yang L, Fan J, Xu J, Jin Y, Yu J, Zhang D, Yang G (2019) Smoking Induced Extracellular Vesicles Release and Their Distinct Properties in Non-Small Cell Lung Cancer. J Cancer 10:3435-3443

Wu J (2009) Understanding of nicotinic acetylcholine receptors. Acta Pharmacol Sin 30:653-655

Wysocki J, Lores E, Ye M, Soler MJ, Batlle D (2020) Kidney and Lung ACE2 Expression after an ACE Inhibitor or an Ang II
Receptor Blocker: Implications for COVID-19. J Am Soc Nephrol 31:1941-1943

Xia J, Wang L, Ma Z, Zhong L, Wang Y, Gao Y, He L, Su X (2017) Cigarette smoking and chronic kidney disease in the general population: a systematic review and meta-analysis of prospective cohort studies. Nephrol Dial Transplant 32:475-487

Xiang G, Xie L, Chen Z, Hao S, Fu C, Wu Q, Liu X, Li S (2021) Clinical risk factors for mortality of hospitalized patients with COVID-19: systematic review and meta-analysis. Ann Palliat Med 10:2723-2735

Xu H, Ling M, Xue J, Dai X, Sun Q, Chen C, Liu Y, Zhou L, Liu J, Luo F, Bian Q, Liu Q (2018) Exosomal microRNA-21 derived from bronchial epithelial cells is involved in aberrant epitheliumfibroblast cross-talk in COPD induced by cigarette smoking. Theranostics 8:5419-5433

Yacoub R, Habib H, Lahdo A, Al Ali R, Varjabedian L, Atalla G, Kassis Akl N, Aldakheel S, Alahdab S, Albitar S (2010) Association between smoking and chronic kidney disease: a case control study. BMC Public Health 10:731

Yamada T, Mikami T, Chopra N, Miyashita H, Chernyavsky S, Miyashita S (2020) Patients with chronic kidney disease have a poorer prognosis of coronavirus disease 2019 (COVID-19): an experience in New York City. Int Urol Nephrol 52:1405-1406

Yang X, Yu Y, Xu J, Shu H, Xia J, Liu H, Wu Y, Zhang L, Yu Z, Fang M, Yu T, Wang Y, Pan S, Zou X, Yuan S, Shang Y (2020) Clinical course and outcomes of critically ill patients with SARSCoV-2 pneumonia in Wuhan, China: a single-centered, retrospective, observational study. Lancet Respir Med 8:475-481

Yeboah MM, Xue X, Javdan M, Susin M, Metz CN (2008) Nicotinic acetylcholine receptor expression and regulation in the rat kidney after ischemia-reperfusion injury. Am J Physiol Renal Physiol 295:F654-661

Yu Fujita TH, Juntaro Matsuzaki, Tsukasa Kadota, Shota Fujimoto, Hironori Kawamoto, Naoaki Watanabe, Kenji Sawaki, Yohei Sakamoto, Makiko Miyajima, Kwangyole Lee, Kazuhiko Nakaharai, Tetsuya Horino, Ryo Nakagawa, Jun Araya, Mitsuru Miyato, Masaki Yoshida, Kazuyoshi Kuwano, Takahiro Ochiya (2020) Early Prediction of COVID-19 Severity Using Extracellular Vesicles and Extracellular RNAs. MedrxiV

Yuan JM, Castelao JE, Gago-Dominguez M, Yu MC, Ross RK (1998) Tobacco use in relation to renal cell carcinoma. Cancer Epidemiol Biomarkers Prev 7:429-433

Zadjali F, Kumar P, Yao Y, Johnson D, Astrinidis A, Vogel P, Gross KW, Bissler JJ (2020) Tuberous Sclerosis Complex Axis Controls Renal Extracellular Vesicle Production and Protein Content. Int J Mol Sci 21

Zamorano Cuervo N, Grandvaux N (2020) ACE2: Evidence of role as entry receptor for SARS-CoV-2 and implications in comorbidities. Elife 9

Zhou H, Cheruvanky A, Hu X, Matsumoto T, Hiramatsu N, Cho ME, Berger A, Leelahavanichkul A, Doi K, Chawla LS, Illei GG, Kopp JB, Balow JE, Austin HA, 3rd, Yuen PS, Star RA (2008) Urinary exosomal transcription factors, a new class of biomarkers for renal disease. Kidney Int 74:613-621

Zhu L, Xiao R, Zhang X, Lang Y, Liu F, Yu Z, Zhang J, Su Y, Lu Y, Wang T, Luo S, Wang J, Liu ML, Dupuis J, Jing ZC, Li T, Xiong W, Hu Q (2019) Spermine on endothelial extracellular vesicles mediates smoking-induced pulmonary hypertension partially through calciumsensing receptor. Arterioscler Thromb Vasc Biol 39:482-495

Zhu QJ, Zhu M, Xu XX, Meng XM, Wu YG (2019b) Exosomes from high glucose-treated macrophages activate glomerular mesangial cells via TGF-beta1/Smad3 pathway in vivo and in vitro. FASEB J 33:9279-9290

Publisher's Note Springer Nature remains neutral with regard to jurisdictional claims in published maps and institutional affiliations. 